J. Dairy Sci. 98:4240-4240

http://dx.doi.org/10.3168/jds.2015-98-6-4240

(C) American Dairy Science Association ${ }^{\circledR}, 2015$.

\title{
Corrigendum to "Effect of microbial inoculants on the quality and aerobic stability of bermudagrass round-bale haylage" (J. Dairy Sci. 98:478-485)
}

\author{
K. G. Arriola, O. C. M. Queiroz, J. J. Romero, D. Casper, E. Muniz, J. Hamie, and A. T. Adesogan
}

The source of Silage Inoculant II (SI) was incorrectly noted in the Abstract (page 478) and in the Materials and Methods section on page 479. Silage Inoculant II was from Lallemand Animal Nutrition (Milwaukee, WI).

The authors regret the error.

\section{REFERENCES}

Arriola, K. G., O. C. M. Queiroz, J. J. Romero, D. Casper, E. Muniz, J. Hamie, and A. T. Adesogan. 2015. Effect of microbial inoculants on the quality and aerobic stability of bermudagrass round-bale haylage. J. Dairy Sci. 98(1):478-485. 